\title{
Civil dialogue and the Citizens' Initiative: accounting for collaboration and competition using the advocacy coalition framework and the strategic action field.
}

\author{
GREENWOOD, J.
}


'This is an electronic pre-publication (including pre-proofs) version of an article published in

H Johansson and S Kalm (eds.) EU Civil Society: Patterns of Cooperation, Competition and Conflict (Basingstoke: Palgrave Macmillan), and available at https://www.palgrave.com/gb/book/9781137500700

1

Chapter 11

EU Civil Dialogue \& the European Citizens' I nitiative:

Accounting for collaboration and competition using the Advocacy Coalition

Framework and the Strategic Action Field

J ustin Greenwood

(Robert Gordon University, Aberdeen, UK)

\section{I ncumbents and challengers}

The European Citizens' I nitiative (ECI) has introduced a largely new set of campaigners working in a fresh 'direct democracy' frame at EU level, alongside an established group of Brussels based EU NGOs seeking to institutionalise an elite 'civil dialogue' between themselves and EU institutions. It therefore provides an ideal empirical setting to evaluate explanatory frameworks designed to account for circumstances where challengers emerge viz. incumbents, and for conflict and collaboration. If 'the worth of any theory is measured by how well it accords with empirical evidence' (Fligstein \& McAdam, 2011, p.23), how well does their 'Strategic Action Field' (SAF) theory perform in comparison to another other meso-level theory designed to account for rival coalitions and the consequences of their interaction, the Advocacy Coalition Framework (ACF)? How well do these accounts perform when seeking to explain collaboration and conflict, as well as change and stability?

Following an account of these contending frameworks and an assessment of their points of comparability, they are put to the empirical test, assisted by the legacy of the respective authors applying their frameworks to European contexts (Marks and McAdam, 1996; Sabatier, 1998). As outlined in Chapter 1, the EU fosters coalition behaviour between civil society organisations, and which is apparent from the account of the incumbent 'civil dialogue order' which follows the exposition of the SAF and ACF frameworks. An account of the development of the European Citizens' I nitiative within the terms of the SAF and ACF frameworks is then provided, with a particular focus on the emergence and establishment of the $\mathrm{ECl}$ in the EU system. The analysis uses evidence about the $\mathrm{ECl}$ drawn from a mixture of official information sources, $\mathrm{ECl}$ campaign websites, participation in three official ECl support events in the period 2012- 
'This is an electronic pre-publication (including pre-proofs) version of an article published in H Johansson and S Kalm (eds.) EU Civil Society: Patterns of Cooperation, Competition and Conflict (Basingstoke: Palgrave Macmillan), and available at https://www.palgrave.com/gb/book/9781137500700

2014', and long-term knowledge of the EU system of interest representation (Greenwood, 1997; 2003; 2007; 2011). A long time frame of analysis is one of the central conditions for the ACF to chart the ways in which belief systems adapt into policy orientated beliefs. Although the incumbents are longer established in EU arenas, the challengers' presence since the 2002-3 Convention on the Future of Europe ('Convention') meets the critical temporal criterion for mutual adaptation so central to the ACF. A concluding section assesses which of the framework best fits the course of events described below.

\section{The Strategic Action Field and Advocacy Coalition Framework: contending paradigms}

Much of what the SAF seeks to offer is captured by Fligstein \& McAdam's key metaphor of 'jockeying around in a game where (actors) are playing to maintain or improve their position' (ibid., p.21). Whilst drawing from institutional theory the core idea of 'socially constructed arenas within which actors with various resource endowments vie for advantage' (ibid., p.3), they seek to go beyond it with a more dynamic and agent centred account of how fields emerge and/or are transformed. A key departure from constructivist accounts, where actors are held to 'follow scripts telling them what to do' (ibid., p.21) is that players in the SAF framework 'make moves and other actors have to interpret them, consider their options, and act' (ibid.,p.5). The authors acknowledge the inheritance from the study of social movements of core concepts of: 'framing, political opportunity, rupture and settlement, episodes of contention, incumbents and challengers' (ibid.,p.22). They offer however a more explicit treatment of power relations by focusing on the ways in which incumbents may use their dominant position to enforce compliance with a particular reference framework such as a governance mechanism. This emphasis on power relations, with implicit overtones of agenda-control found in the second and third dimensions of power (Lukes, 1974), is also held to make the SAF better equipped to account for processes of stability and order than the legacy provided by the study of social movements. Nonetheless, in common with field theories as a whole, the homogenising effect on organisations belonging to a particular field (Chapter 1 ) may lead it to over-emphasise collaboration and to under-specify conflict, partly because the treatment of power is often more implicit than explicit in the SAF framework.

The SAF's attempt to incorporate power relations does however provide a point of distinction from another meso-level theory grounded in iterative interactions in socially constructed orders, the Advocacy Coalition Framework (ACF). Nonetheless, the ACF gives a central place to goal conflicts, tracing the 
'This is an electronic pre-publication (including pre-proofs) version of an article published in

$H$ Johansson and S Kalm (eds.) EU Civil Society: Patterns of Cooperation, Competition and Conflict (Basingstoke:

Palgrave Macmillan), and available at https://www.palgrave.com/gb/book/9781137500700

source of policy change to changes in the belief systems of contending advocates in a policy sub-system during interactions over long periods of time and from there to governance systems (Sabatier, 1988). The ACF policy system/subsystem is explicitly referenced by Fligstein \& McAdam as their 'meso level social order,' (Fligstein \& McAdam, 2012, p.9) which they illustrate through a 'Russian doll' metaphor (p.3). Whilst the ACF is a theory of policy change, and the SAF an account of the emergence and transformation of fields, the foundations of interaction between rival advocates as a source of change and stability make them well suited for comparison.

Differentiation between the SAF and ACF is not about what they are trying to account for, but over their treatment of power, as well as degrees of emphasis between structure and agency. In the SAF model, governance mechanisms are identified as a means of enforcement of the dominant order, whereas the ACF model places policy makers participating alongside expert advocates in a more pragmatically positioned shared learning knowledge and information pool. These sources of expertise help legislators to chart a course in times of uncertainty in the ACF model, much in the same way predicted by institutional theory where actors follow scripts (routines, advice, best practice) telling them what to do. This differs from the emphasis on agency in the Social Action Field where 'actors with varying resource endowments vie for advantage' (Fligstein \& McAdam, 2011, p.3). The ACF emphasis on the ways in which skilled policy entrepreneurs exercise leadership in linking solutions to problems to bring about changes in policy (Sabatier and Weible, 2007, p.203; Kingdon 1995 in ibid.) also distinguishes it from the SAF. Whilst the latter lays emphasis on the 'social skills' of field actors, it is more a relational concept in interpretation of the acts of others and devising responses. Nonetheless, the extent of the connection between the two frameworks is apparent from revisions of the ACF framework seeking to draw explicitly upon McAdam's comparative work on social movements (Mc Adam et al, 1996; Sabatier and Weible, 2007), and in particular upon the inter-organisational and inter-personal linkages which tie network actors together (chapter 1 ). Ruzza's concept of movement advocacy coalitions (chapter 1, chapter 2) to some extent draws upon each tradition, although not to the extent of changing the identity of coalition members in the way in which contextual belief systems binds together participants in the advocacy coalition framework.

\section{Incumbents in search of a 'Civil Dialogue'}

Shortly before the Convention set about drafting a Constitutional Treaty for Europe (eventually, the Lisbon Treaty), a long-term issue about how to make a 
'This is an electronic pre-publication (including pre-proofs) version of an article published in

H Johansson and S Kalm (eds.) EU Civil Society: Patterns of Cooperation, Competition and Conflict (Basingstoke: Palgrave Macmillan), and available at https://www.palgrave.com/gb/book/9781137500700

better connection between EU institutions and civil society had re-surfaced prominently in the European Commission's 2001 White Paper on Governance (WPG). The EU shares with other transnational political systems a structural distance from civil society, acute because of the extent of EU derived legislation in member states coupled with limited participation in European Parliament elections (43 per cent turnout in 2009 and 2014). The traditional pathway followed by EU institutions in seeking to address these problems had been to use interest groups and the like as, inter alia, the best available proxy for civil society, and the WPG set about trying to introduce a new set of rules to govern it. The WPG was, in essence, a search for participative based legitimacy, and if EU institutions were to be dependent on dialogue with interest groups it needed to be placed on a legitimate structured footing. As with other international organisations, the choice juxtaposed a pluralist pathway of competition between a teeming population of groups underpinned by a regulatory framework centred on transparency and redressing information asymmetries, or a more corporatist pathway trodden by other international organisations involving special recognition of a small number of groups with certain desired criteria.

The WPG incorporated thinking from a policy document issued in 2000 in the name of the European Commission President and a Vice President, 'The Commission and NGOs: building a stronger partnership' ('Partnership') (European Commission, 2000). The 'Partnership' paper had proposed desired properties for NGOs of 'representativeness... of their roots in the different Member States of the European Union' and 'their track record and ability to contribute substantial policy inputs' (European Commission, 2000, p.9). One of the lead NGOs established at EU level, the Platform of European Social NGOs (Social Platform), submitted a response on behalf of itself and two longer established 'families' of EU NGOs (Development, and Environment); in the terms of chapter 1, this was a 'third level' meta network response on behalf of 'second level' platform organisations. The Social Platform was a creation of EU institutions in the mid-1990s with a brief of bridging EU institutions with citizens, but consisting of members who were other NGOs in the social policy field organised at EU level. Its claims to legitimacy therefore rest on functional, rather than territorial, representativeness, and its response to the 'Partnership' paper unsurprisingly baulked at the concept of territorial representativeness, proposing instead a legal basis to a 'civil dialogue' (Social Platform, 2000). In pursuit of its remit it held two open events for citizens in Brussels during 1997-8, but which were largely unsuccessful in attracting a presence beyond the 'usual suspects' of NGOs in the 'Brussels bubble'. These events framed 'bridging the EU with citizens' as the need for a 'civil dialogue' between EU institutions and NGOs 
'This is an electronic pre-publication (including pre-proofs) version of an article published in

$H$ Johansson and S Kalm (eds.) EU Civil Society: Patterns of Cooperation, Competition and Conflict (Basingstoke:

Palgrave Macmillan), and available at https://www.palgrave.com/gb/book/9781137500700

5

organised at EU level, and the choice of the Social Platform to deliver a collective response to the consultation on the 'Partnership' paper crystallised both the emergence of a 'family of families' of EU NGOs and the place of the Social Platform at its head.

The WPG incorporated the thinking in the Partnership paper on the justification that 'with better involvement comes greater responsibility' (European Commission, 2001, p.15). It therefore offered a system of 'more extensive partnership arrangements' for groups who could 'furnish guarantees of representativity and prove their capacity to relay information or lead the debate in the Member States' (European Commission, 2001, p.17). The responses to the WPG from the European Parliament, and from member states with pluralist traditions, discouraged this corporatist approach, such that by the time the Commission converted the WPG into a concrete framework of consultation standards, 'representativeness' had dissolved into a weaker and more pluralist form involving transparency of membership (European Commission, 2002). Consultation over these consultation standards was the moment at which the Social Platform sought to re-frame 'representativeness' from a territorial property into a functional one, coupled with the 'track record' which had appeared in the Partnership document (Social Platform, 2002). A 'civil dialogue', based around itself at the at the head of a 'family of families' of EU NGOs, had become the Social Platform goal, in much the way foreseen by SAF 'jockeying for position'.

A key entrepreneur in the emergence of the Social Platform at the head of a family of families of NGOs had been its President, Giampiero Alhadeff, who also held the position of Secretary General of another EU NGO well linked to the trade union movement. Since the 1992 Treaty on European Union, trade unions at EU level have participated in a 'social dialogue' with employer organisations with special delegated powers and institutional recognition, and which provided an aspiration for the NGOs 'civil dialogue' campaign. Alhadeff's proactive actions viz. trade unions on behalf of the Social Platform, co-opting them into an alliance seeking something potentially competitive to their social dialogue, and adding them as an associate of the new family coalition of NGOs, looks much like the emphasis on actor social skills cast in the SAF account. The ACF has no corresponding tool, but incorporates of a slightly different mechanism focused on ways through which policy entrepreneurs seek to attach solutions to problems (Kingdon, 1995), relating civil dialogue to the EU's legitimacy deficit. The new NGO family lobbied the Convention for a Civil Dialogue as the Act4Europe coalition with the trade union movement. In SAF terms, it was an attempt to 
'This is an electronic pre-publication (including pre-proofs) version of an article published in

$H$ Johansson and S Kalm (eds.) EU Civil Society: Patterns of Cooperation, Competition and Conflict (Basingstoke:

Palgrave Macmillan), and available at https://www.palgrave.com/gb/book/9781137500700

6

'reinforce the dominant logic, and safeguard the interests of the incumbents' (Fligstein \& McAdam, p.6). However, the Convention simply codified long standing practices of dialogue between EU institutions and civil society into parts 1-3 of Article 11 of the Treaty on European Union, but without any new status, rights or nomenclature attached to it. In essence, Articles 1-3 require EU institutions to do nothing more remarkable than engage in an institutionalised dialogue with whoever is so inclined to talk with them about their policy proposals.

Despite the unsuccessful Civil Dialogue campaign, Act4Europe developed after the Convention into an enduring alliance as the Civil Society Contact Group (CSCG), with a secretariat shared between different NGO families and hosted by one of the core family members. In the ACF framework a coalition is foreseen as a shared belief advocacy community solving collective action problems and a willingness to distribute costs fairly. In the SAF framework, its creation reflects the 'creation of identities, political coalitions, and interests to promote the control of actors vis-à-vis other actors' (ibid., p.6-7). After an initial period of expansion, CSCG members have taken the decision to limit the size and collective identity of the CSCG to themselves. The wealthiest members of these families tend to act at the periphery because of their self-sufficiency, while the poorest members are strongly reliant upon the core members to develop a critical mass for their campaigns. At the core are NGOs with sufficient resources to host key coalition facilities yet sufficient needs to require working coalitions for most of their campaigns. These descriptions match the roles of coalition members, where resource self-sufficient families of NGOs (Development, and Environment) operate at the periphery and the poorest (Culture, Education) remain dependent on the two central coalition members and hosts since its inception, the Social Platform and (since around the start of the $\mathrm{ECl}$ ) the European Public Health Alliance (EPHA). The Social Platform did nonetheless achieve its own place with the social partners at the twice-yearly informal ('night before' the full meeting of the) Employment, Social Policy, Health and Consumer Affairs Council (EPSCO) of the EU Council of Ministers. The civil dialogue campaign continued beyond the Convention in the form of advocacy to resurrect a 'European Statute of Associations' led by a group of French NGOs (Kendall \& Fraisse, 2011), and a proposal for a 'Compact' of quasi-legal standards to underpin dialogue between organisations and EU institutions comparable with models in some member states.

The Social Platform was to re-advocate an accreditation system during the period when the $\mathrm{ECl}$ was in its formative process. It responded to the European 
'This is an electronic pre-publication (including pre-proofs) version of an article published in $H$ Johansson and S Kalm (eds.) EU Civil Society: Patterns of Cooperation, Competition and Conflict (Basingstoke: Palgrave Macmillan), and available at https://www.palgrave.com/gb/book/9781137500700

Commission's 2010 public consultation on how to operationalise the $\mathrm{ECl}$ by attempting instead to re-frame the issue into how to achieve its ambition for a civil dialogue:

'Social Platform calls on the European Commission to launch a public consultation on how to implement the first part of the Lisbon Treaty article 11 on civil dialogue...Social Platform would like to stress that the right to petition is not the only new instrument related to participatory democracy that the Treaty of Lisbon introduces into EU decision making processes. The first part of article 11 (which regards civil dialogue) requires all EU institutions to implement new mechanisms of dialogue with civil society (as opposed to consultations, run by the European Commission as it is the case now). Given that the European Commission has not revised its procedures to dialogue with citizens for almost a decade, we believe it is time for the European Commission to discuss with civil society organisations how this new mechanisms of dialogue should take place in the future between EU institutions and organised civil society.' (Social Platform, 2010b; original wording)

Two other members of the Social Platform 'family' submitted identical responses. In SAF terms, the response of the Platform was entirely readable as an attempt by a 'skilled strategic actor in (an) incumbent group(s) to produce and reproduce a status quo...in response to an emerging crisis, incumbents are apt- at least initially - to appeal to the status quo' (Fligstein \& McAdam, 2011, p.7).

The civil dialogue campaign of today continues to make explicit reference to the social dialogue:

next to the social dialogue between trade unions and employers, there is a need for a civil dialogue that can enrich our representative democracies with participatory democracy...Civil society organisations do not currently take part in structured dialogue and yet it is these groups who are directly affected by European decisions (Social Platform, 2014a) (emphasis added).

'Jockeying for position' seems a plausible explanation for discourse in which citizens are seemingly forgotten and advocacy groups positioned as the ones directly affected by European decisions. But in SAF terms, the Civil Dialogue concept was never sufficiently appealing to withstand criticism of a participatory model based around 'Brussels talking to Brussels' (European Commission, 2002)., i.e. 'lobby groups' as surrogates for an otherwise absent civil society in dialogue with EU institutions. The Convention set in motion an altogether 
'This is an electronic pre-publication (including pre-proofs) version of an article published in

H Johansson and S Kalm (eds.) EU Civil Society: Patterns of Cooperation, Competition and Conflict (Basingstoke:

Palgrave Macmillan), and available at https://www.palgrave.com/gb/book/9781137500700

8

different participatory mechanism in the form of the European Citizens'

I nitiative. The SAF framework predicts that 'as the commitment to the ongoing structure collapses, new actors can be expected to join the fray' (Fligstein \& McAdam, 2011, p.10).

\section{The Challengers: the $\mathrm{ECl}$ and a direct participatory frame}

Towards the end of the Convention, a group of direct democracy activists, clustered around the German based NGO Democracy International, successfully lobbied (de Clerk Sachsse, 2012; Kaufman, 2012) for the introduction of a new direct participation instrument, the European Citizens' Initiative. This wholly new idea in an EU context struck a chord sufficient to become incorporated into the 2009 Lisbon Treaty as Article 11(4) of the Treaty on European Union (TEU). The Treaty provision is implemented by Regulation 211/2011 of the European Parliament and Council, in which one million validated signatures collected from EU citizens during a 12 month registration period, drawn from at least a quarter of member statesii, with weighted minimum quotas specified for each state, can request the European Commission to bring forward proposals on any topic falling within EU Treaty competencies.

The direct democracy activists mobilised around a direct participatory element for the EU were entirely different from the 'associative democracy' EU NGOs who had sought the insertion of a civil dialogue into the draft Treaty, such that the latter had played no role in lobbying for the insertion of the $\mathrm{ECl}$ into the Treaty drafted by the Convention (de Clerk Sachsse, 2012). In ACF terms, the respective 'policy core policy preferences' had 'been a major source of cleavage for some time' (Sabatier and Jenkins Smith, 1999, p.134), where 'policy core policy preferences might be the stickiest glue that binds coalitions together' (Sabatier and Weible, 2007, p.195). In what follows, 'the ACF assumes that policy participants strive to translate components of their belief systems into actual policy before their opponents can do the same' (ibid., p.196) provides a script to follow, just as much as the SAF emphasis on governance frameworks as a means for an incumbent group to assert the status quo.

If most of the established EU civil society organisations initially ignored the new direct participatory instrument, a small number engaged with it as a form of positioning in much the way anticipated by the SAF emphasis on 'vying for advantage'. One key member of the Social Platform operated an unofficial signature collection campaign in the period between the adoption of the Lisbon Treaty in 2009 and the official start of the ECl in 2012. The European Disability 
'This is an electronic pre-publication (including pre-proofs) version of an article published in

$H$ Johansson and S Kalm (eds.) EU Civil Society: Patterns of Cooperation, Competition and Conflict (Basingstoke:

Palgrave Macmillan), and available at https://www.palgrave.com/gb/book/9781137500700

Forum's (EDF) campaign '1million 4disability' was the most successful of the unofficial campaigns in collecting signatures ${ }^{\text {iii }}$, yet it failed to build on its success by launching a campaign after the official start of the ECI. EDF is one of a number of disability advocacy NGOs in the Social Platform, and the EDF 'pilot' campaign seems to be captured by the metaphor of 'jockeying for position' when its Director reflected that it had been

Beneficial to EDF in terms of recognition by the EU institutions as a very representative organization which was able to mobilise such a large number of its members and citizens.' (Carlotta Besozzi, correspondence, 4.6.2013).

The group of direct democracy activists mobilised around getting the $\mathrm{ECl}$ into the EU Treaties were also those who mobilised around the experimental 'Citizens Agoras' of 2008-9 led by Commissioner Wallstrom, around which the 'civil dialogue' crowd had been no more than peripheral figures. The concept has since been adapted in 'Citizens Dialogue' roadshow events around the member states following on from the 'European Year of Citizens 2013,' in which the 'civil dialogue' organisations needed to show willing. For the Social Platform, a confederated status has meant that it has been unable to play a leading role in these Citizens' events, yet at the same time its advocacy 'on behalf of the citizens' required it to at least show support, reflected by its membership of the steering committee of the 'European Year of Citizens Alliance 2013' (EYCA) led by a network based outside of Belgium. This trajectory is also evident in its belated reconciliation with the $\mathrm{ECl}$ as a 'second tier' supporter of the most successful ECI signature collection campaign led by the trade unions against water privatisation, considered in further detail below. This behaviour is foreseen by the SAF's concept of a 'refurbished institutional re-settlement' (Fligstein \& McAdam, p.10), while the advocacy coalition framework also comfortably fields the change with its focus on policy orientated learning where actors pragmatically adjust to new realities (Sabatier, 1988), particularly over aspects than are means ('secondary policy beliefs' in the ACF framework) rather than ends.

The requirement for $\mathrm{ECl}$ s to be organized by a Citizens' Committee comprising seven individuals from seven member states reflects a desire to draw a clear distinction for the measure from dialogue involving EU institutions and 'representative associations' (Article 11.2, TEU). The institutional Vice-Presidents responsible for the measure from the European Commission and European Parliament have emphasised the intention that the measure should not be 'hijacked by lobbyists' (Mason, 2012) and that 'an ECl is not for NGOs, but for all citizens' (EurActiv, 2011). Likewise, the websites of a number of the first official 
'This is an electronic pre-publication (including pre-proofs) version of an article published in

$H$ Johansson and S Kalm (eds.) EU Civil Society: Patterns of Cooperation, Competition and Conflict (Basingstoke: Palgrave Macmillan), and available at https://www.palgrave.com/gb/book/9781137500700

$\mathrm{ECl}$ campaigns have made a virtue of the distinction between themselves and $\mathrm{EU}$ level professionalised advocacy organisations in Brusselsiv. Despite this clear demarcation, it can be expected that the individual members of Citizens' Committees will have links to advocacy organisations in varying degrees. Whilst registering an initiative which falls within EU competencies is a relatively straightforward process, the data protection requirements for systems for online signature collection, in particular, are burdensome to the point that navigating them requires collective resources well beyond those of seven private individuals. The threshold of one million signatures requires access to established networks, which, to date, only three campaigns (linked to the trade union movement, the Catholic Church, and animal welfare organisations, respectively) have been able to achieve. Only the first of these campaigns was driven by advocacy organisations established at EU level, whereas the others originated among established movements in the member states.

Establishing links between Citizens' Committees and supporting organisations is not a straightforward task. The Commission requires Committees to declare sources of financial support on the website, but most declare funding of less than $€ 10,000$, often from private individuals. Onward links from the $\mathrm{ECl}$ website to those of individual campaigns are another way of linking citizens committees to advocacy organisations. Following these, and other, links, the European Citizens' Action Service (ECAS) support unit for the $\mathrm{ECl}$ concludes that only eight of the $47 \mathrm{ECl}$ s so far presented to the European Commission originate from EU wide organisations, while as many campaigns originate from newly formed entities (ECAS, 2014; see also Bouza Garcia and Greenwood, 2014). Most registered ECIs originate away from Brussels, either as part of transnational movements (rather than NGOs) or among advocacy organisations in the member states. In addition to these are the 20 would-be campaigns which were refused registration by the European Commission, of which only two originate from EU NGOs (Bouza Garcia and Greenwood, 2014; figures updated). The Director of the Greenpeace European Unit reflected that

'An ECl may be a useful tool as part of a campaign that aims to raise awareness and create some political momentum on lesser known issues of public interest that otherwise get little media and political attention. I do not rate it very highly as a point of leverage on the big legislative issues that Greenpeace usually fights on...the outcome from an $\mathrm{ECl}$ depends on the goodwill of the Commission. With the current Commission, a million euro spent on lobbyists gets you further than a million signatures, regrettably...we do not rule out starting another $\mathrm{ECl}$, but the effort involved is significant, and can be a distraction from keeping up with and countering industry lobbyists (J orgo Riss, correspondence, 14.6.2013). 
'This is an electronic pre-publication (including pre-proofs) version of an article published in

$H$ Johansson and S Kalm (eds.) EU Civil Society: Patterns of Cooperation, Competition and Conflict (Basingstoke: Palgrave Macmillan), and available at https://www.palgrave.com/gb/book/9781137500700

With its lack of mandation on EU institutions, the $\mathrm{ECl}$ is primarily an agenda-setting tool, and therefore of limited appeal to professionalised EU NGOs which have other institutionalised channels to raise their issues, ranging from advisory committees and EU policy forums through to the bilateral networks they have built in Brussels. Whilst both Greenpeace and Friends of the Earth conducted pilot signature collection campaigns before the official start of the measure, and Friends of the Earth make an unsuccessful attempt to register an $\mathrm{ECl}$ soon after its official start, each of these campaigns were conducted through their offices in the member states rather than their Brussels EU 'policy' offices. The present-day EU system more incentivises institutional advocacy more than public campaigning (Warleigh, 2001; Sudbery, 2003), and in this context the view of Riss, the Head of the Greenpeace EU policy office, is unsurprising. Where Citizens' I nitiatives have direct law making effect, such as California, so the measure has been taken up for use by systemic lobby groups attached to the political system, but where they lack legislative effect the measure is largely left to outsiders (Smith, 2009; Cuesta Lopez, 2012).

By way of emphasis of the difference between the professionalised world of Brussels lobbying and the majority of $\mathrm{ECl}$ campaigns, the thirteen campaigns running the full course without meeting the signature threshold have fallen short by a long way, ranging from 780 to 285,000 signatures. At the highest end of this spectrum is the Unconditional Basic Income (UBI) campaign, originating from the radical transnational ATTAC movement. For the remaining campaigns the collection of signatures seems to have been one of a number of goals; the co-ordinator of one Campaign Committee responded pointedly to a request to disclose the final signature tally that 'I'm afraid we feel that the importance and success of an $\mathrm{ECl}$ is not measured by the number of signatures' (correspondence, 5.2.2014). A commentator from Democracy International, coorganiser of an 'ECl Day' conference held in April 2013, reflected on her way home from the day's proceedings that:

'Many ECl organisers admitted that they had launched an $\mathrm{ECl}$ merely for reasons of public relations and networking, while lacking belief that they could actually reach the amount of one million signatures.' (Pfafferott, 2013)

There is supporting evidence from some campaigns for this observation, but it does not accurately capture the diversity of $\mathrm{ECl}$ campaigns. There can be little doubt that for some the mechanism has provided an opportunity to get 
'This is an electronic pre-publication (including pre-proofs) version of an article published in

H Johansson and S Kalm (eds.) EU Civil Society: Patterns of Cooperation, Competition and Conflict (Basingstoke:

Palgrave Macmillan), and available at https://www.palgrave.com/gb/book/9781137500700

12

noticed, establish an organisation structure and attract longer-term supporters. The 30kmh in urban areas and A High Quality European Education for All campaigns which themselves saw the main legacy in these ways, while other campaigns were linked to promoting a project (in one case, an EU news channel) or seemingly linked to career interests in EU politics. Act4Growth was led by a member of the European Economic and Social Committee, while a number of campaigns bear the hallmarks of student activists with an EU studies flavour, or simply cohorts of interested Masters Students experimenting with the device, withdrawing a campaign shortly after successful registration.

There are a number of campaigns which are clearly using the $\mathrm{ECl}$ for much more than jockeying for position. The trade union movement, in particular, had long demonstrated its ability to combine institutional advocacy at EU level with mass mobilisation for protest politics (Leiren and Parks, 2014). This made it well placed to take up the concept of a direct participatory element, initially through an unofficial campaign before the start of the $\mathrm{ECl}$, and afterwards by conducting (on a different topic) the most successful $\mathrm{ECl}$ signature collection campaign to date. For the established trade union movement, the $\mathrm{ECl}$ was a successful means to ensure that general principles of market liberalisation did not become institutionalised as a source of water privatisation at national level. The European Commissioner for the Internal Market and Services, Michel Barnier, responded with an explicit statement that this was not, and never had been, his goal, and gave an undertaking that the Concessions Directive, the focus of trade union anxieties, did not mean privatisation through the back-door (European Commission, 2013). Whilst it is impossible to assess whether the campaign had achieved more than a line in the sand, and, if so, whether a lobbying campaign might have succeeded in defeating any such proposal, the use of the ECI seems to be an informed tactical choice in an EU orientated campaign against privatisation. An alternative explanation could however be that social partner status meant that trade unions operating at EU level had no need to perceive the new $\mathrm{ECl}$ as a challenge to their established position.

Other $\mathrm{ECl}$ campaigns also seem readable in the straightforward terms of the advocacy issues they sought to introduce to EU politics. Campaigns aimed at legalising cannabis, and ending legalised prostitution, introduced new topics to EU politics, with the former successful with its registration and which acquired well over 100,000 signatures. Among withdrawn initiatives, the seemingly maverick campaign to punish Switzerland for its alleged mistreatment of foreign workers looks on closer inspection to have been a tactical means of getting publicity in the Swiss media, never progressing to the stage of signature 
'This is an electronic pre-publication (including pre-proofs) version of an article published in

H Johansson and S Kalm (eds.) EU Civil Society: Patterns of Cooperation, Competition and Conflict (Basingstoke: Palgrave Macmillan), and available at https://www.palgrave.com/gb/book/9781137500700

collection. The $€ 150,000$ spent by an alliance led by producer related organisations on the Dairy Cow Welfare campaign, withdrawn after three months, seems to have simply been an underestimation of the resources required to achieve the signature threshold. The 'jockeying for position' metaphor similarly fails to capture the diversity involved with refused requests for registrations. Five Campaign Committees have taken the expensive route of referring to the European Court of J ustice the European Commission's rejection of their application to register an $\mathrm{ECl}$ campaign. $v$ This may be a means to prolong, or bring further life to, campaigns, but only one of the five (calling for a cancellation of Greek debt) is unlikely to have been surprised by their rejection, with the other four having first obtained detailed legal counsel before lodging their application to register an initiative. The most recent of these cases, the 'Stop TTIP' (Transatlantic Trade and Investment Partnership), originated with Democracy International, who may have wanted a high-profile campaign as an $\mathrm{ECl}$, but which had little need for positioning as the established direct democracy advocate. By contrast, the ACF reliance upon institutional socialisation and policy sub-systems seems to allow for a smoother integration of $\mathrm{ECl}$ campaigners than 'jockeying for position'.

The $\mathrm{ECl}$ continues to feature regularly in lists of 'innovations' drawn up by EU institutions about the way in which the Lisbon Treaty strengthens connections with citizens, with its direct participatory character regularly highlighted. As such, both the European Commission and the European Parliament have gone to some lengths to try to make the measure work. During the establishment phase of the $\mathrm{ECl}$, the Commission lent its own servers to campaigns experiencing difficulties with meeting the technical specifications for online signature collection. In seeking to promote the measure, the Commission has partnered with those few EU NGOs founded on a niche frame of 'citizens direct', and most notably with the European Citizens' Action Service (ECAS). ECAS has differentiated itself from the civil dialogue crowd since its foundation in 1991, fulfilling contracts with the European Commission aimed at establishing direct connections with citizens, such as telephone hotlines for citizens experiencing difficulties in enforcing their free movement rights. ECAS was one of the very few EU NGOs to join activists from an early stage in detailed campaigning work in support of the $\mathrm{ECl}$. Whilst this positioned it well to host the 'Citizens House' support mechanism for the $\mathrm{ECl}$, part-funded by the European Commission, the $\mathrm{ECl}$ more seems to present a moment when a longer standing ECAS outlook about direct forms of citizen participation has come to fruition, rather than 'jockeying for position'. In the Brussels 'field', ECAS is neither a civil dialogue incumbent nor challenger, nor a contending advocate, but more an 
'This is an electronic pre-publication (including pre-proofs) version of an article published in $H$ Johansson and S Kalm (eds.) EU Civil Society: Patterns of Cooperation, Competition and Conflict (Basingstoke: Palgrave Macmillan), and available at https://www.palgrave.com/gb/book/9781137500700

organisation bridging the two worlds of civil dialogue and direct democracy. It has joined the civil dialogue crowd in advocating quasi-legal standards (or more) to underpin dialogue between civil society organisations and EU institutions, yet direct democracy activists have a central position in its networks. Ruzza's concept of a movement advocacy coalition, in which coalition partners span professionalised social movements (Chapters 1 and 2; see also Chapter 5 on professionalised social movements) and NGOs, without necessarily changing the identity of participants, seems to better capture what ECAS is about than do either the SAF or ACF.

\section{Conclusion: the ACF and SAF interpretations compared}

Aspects of the $\mathrm{ECl}$ 's introduction into a field dominated by an alternative frame of reference are open to narration as a story of incumbents and challengers interactively jockeying for position. The question is more whether the SAF does justice to the full empirical picture which emerges, and whether it adds value to existing explanatory tools. On these criteria there is room for doubt. The $\mathrm{ECI}$ brings a new instrument to cultivate a 'European public sphere', has already mobilised a new set of actors to engage with EU public policy, and challenges a group of established incumbents to include public campaigning in support of their advocacy with EU institutions. ECl campaigns contain substantial diversity, which key SAF metaphors fail to capture in breadth. The $\mathrm{ECl}$ was designed to be a change agent in a field which needed instruments of direct citizen participation, and will require some re-adjustment in a community set up for institutionalised advocacy. In this, the $\mathrm{ECl}$ is the key policy event, and the emphasis on the ways in which organisations can learn to live with an event which may initially be interpreted as challenging, and even turn it to their advantage, is already well captured by the Advocacy Coalition Framework. Issues surrounding withdrawn and rejected initiatives, and responses to administrative actions of the European Commission, are also difficult to explain using the SAF framework. The European trade union movement's use of the $\mathrm{ECl}$, and the niche occupied by ECAS, involve cases where the two worlds of institutionalised politics and direct participation have been successfully mixed. Neither the SAF nor the ACF frameworks are particularly helpful in placing organisations capable of working in, and between, these frames. As ever, a combination of explanations couched in rational choice, and institutional, traditions seems to prevail. The SAF tries to be this, giving it an advantage over the more pluralist ACF in its more explicit treatment of power relations, and providing it with a better ability to predict outcomes. But its emphasis on the role of agency more than structure, in actors making moves and others having 
'This is an electronic pre-publication (including pre-proofs) version of an article published in

$H$ Johansson and S Kalm (eds.) EU Civil Society: Patterns of Cooperation, Competition and Conflict (Basingstoke: Palgrave Macmillan), and available at https://www.palgrave.com/gb/book/9781137500700

15

to interpret them, leads it to be more a theory of change than stability, despite its claims to the contrary. This emphasis helps it to develop mechanisms of change, such as social skills, which are valuable but hardly innovative, and give it some advantage over the ACF where mechanisms of change are often more implicit than stated. These points may be fair game to those who see in both concepts a tendency to state the obvious. As the SAF framework models, incumbents can be expected to use governance mechanisms to enforce stability, but even there the SAF casts a restless process:

II our view, SAFs tend toward one of three states: unorganized or emerging, organized and stable but changing, and organized and unstable and open to transformation.' (Fligstein \& McAdam, 2011, p.1)

In this process,

'Challengers can be expected to engage in a constant testing of the stability of the field, probing through their actions to assess the overall vulnerability of incumbents or more proximate rivals' (ibid., p.15).

Empirical evidence of this from the $\mathrm{ECl}$ is scarce on the ground. In sum, it seems that the SAF is strong where it comes to explaining change, and in these circumstances better than the ACF because it is centred on incumbents and challengers locked in a power game. The ACF, seemingly, can account for both change and stability because the source of both lies in the belief systems of rival advocates and exchanges via the institutional mechanisms through which they engage with each other. Yet the ACF has its origins in the pluralistic politics of the environment, which it seems ideally suited to explain. And yet neither concept are comfortable where organisations can switch easily between frames of institutionalised politics and protest politics, and between organised civil society and direct participation models. Without explicit constructivist mechanisms it is easy to lose sight of the SAFs claim to have one foot in each of the camps of institutionalism and rational choice. 
'This is an electronic pre-publication (including pre-proofs) version of an article published in $H$ Johansson and S Kalm (eds.) EU Civil Society: Patterns of Cooperation, Competition and Conflict (Basingstoke: Palgrave Macmillan), and available at https://www.palgrave.com/gb/book/9781137500700

\section{References}

Bouza Garcia, L (2012) 'New Rules new Players? The ECl as a source of competition and contention in the European Public Sphere', Perspectives on European Politics and Society, 13, 3, 337-351.

Bouza Garcia, L and Greenwood, J (2014) Bouza Garcia, L. and Greenwood, J. (2014) 'The European Citizens' I nitiative: a new sphere of EU politics?' Interest Groups \& Advocacy, 3, 246-267.

Browne, W. P. (1990) 'Organized interests and their issue niches: A search for pluralism in a policy domain', Journal of Politics, 52, 477-509.

Cuesta López, Víctor. 2010. 'The Lisbon Treaty's Provisions on Democratic Principles: A Legal Framework for Participatory Democracy', European Public Law Review 16, 1, 123-138.

De Clerck-Sachsse, J (2012) 'Civil Society and Democracy in the EU: The Paradox of the European Citizens' Initiative', Perspectives on European Politics and Society, 13, 3, 299-311.

EurActiv (2011) Experts strive to make citizens initiative work, http://www.euractiv.com/future-eu/experts-strive-citizens-initiative-work-news503261, accessed on 09.02.2014.

European Citizen Action Service (ECAS) (2014) European Citizens' I nitiative http: // citizenhouse.eu/index.php?option=com_content\&view $=$ article\&id $=106 \& / \mathrm{t}$ emid $=175 \&$ lang $=$ en accessed on 25.06.2014

European Commission (2000) The Commission and NGOs: building a stronger partnership" (COM (2000) 11)

http://ec.europa.eu/transparency/civil_society/ngo/index_en.htm accessed on 25.11.2014.

European Commission (2001) European Governance: A White Paper, Brussels, Commission of the European Communities, COM(2001) 428, http://europa.eu/legislation summaries/institutional affairs/decisionmaking pro cess/I10109_en.htm accessed on 25.11.2014.

European Commission (2002) 'Towards a Reinforced Culture of Consultation General Principles and Minimum Standards for Consultation of Interested Parties by the Commission', $\operatorname{COM(2002)~} 704$ final, 
'This is an electronic pre-publication (including pre-proofs) version of an article published in $H$ Johansson and S Kalm (eds.) EU Civil Society: Patterns of Cooperation, Competition and Conflict (Basingstoke: Palgrave Macmillan), and available at https://www.palgrave.com/gb/book/9781137500700

http://ec.europa.eu/governance/docs/comm_standards_en.pdf accessed on 25.11.2014.

European Commission (2005) 'EU Forum Science in Society: Report of the Specific Session "Civil Society and Science: an increased role for NGOs?",' Brussels, 10 March 2005, RTD-C2/VWM, http://europa.eu.int/comm/research/conferences/2005/forum2005/docs/library report_ong_en.pdf, accessed on 5.09.2006.

European Commission (2013) 'Exclusion of Water from the Concessions Directive: statement by Commissioner Barnier', http://ec.europa.eu/commission_20102014/barnier/headlines/speeches/2013/06/20130621_en.htm accessed on 11.02.2014.

European Disability Forum (undated) Sign for Disability Rights, http://www. Imillion4disability.eu/ accessed on 25.6.2014.

Fligstein, N and McAdam, D (2011) 'Towards a General Theory of Strategic Action Fields', Sociological Theory, 29, 1, 1-26.

Fligstein, N and McAdam, D (2012) A Theory of Fields (Oxford: Oxford University Press).

Gemperli, S (2012) EU citizens' finance Swiss popular initiative, Neue Bürcher, Zeitung, http://www.nzz.ch/aktuell/schweiz/eu-buerger-finanzieren-schweizervolksinitiative-1.17694565, accessed on 09.02.2014.

Greenwood, J (1997) Representing Interests in the European Union (Basingstoke and New York: Palgrave Macmillan).

Greenwood, J (2003) Interest Representation in the European Union (Basingstoke and New York: Palgrave Macmillan).

Greenwood, J (2007, $2^{\text {nd }}$ edition) Interest Representation in the European Union (Basingstoke and New York: Palgrave Macmillan).

Greenwood, J (2011, $3^{\text {rd }}$ edition) Interest Representation in the European Union (Basingstoke and New York: Palgrave Macmillan).

Greenwood, J. and Halpin, D. (2007) 'The European Commission and the Public Governance of Interest Groups in the European Union: seeking a niche between accreditation and laissez-faire', Perspectives on European Politics and Society, 8, 2, 190-211. 
'This is an electronic pre-publication (including pre-proofs) version of an article published in H Johansson and S Kalm (eds.) EU Civil Society: Patterns of Cooperation, Competition and Conflict (Basingstoke: Palgrave Macmillan), and available at https://www.palgrave.com/gb/book/9781137500700

Greenwood, J and Dreger, J (2013) 'The Transparency Register: a vanguard of strong European lobby regulation?' Interest Groups and Advocacy, 2, 2, 139162.

Kaufman, B (2012) 'Transnational 'Babystep': The European Citizens' I nitiative', in M Setälä and T Schiller (eds.) Citizens' Initiatives in Europe: procedures and consequences of agenda-setting by citizens (Basingstoke and New York: Palgrave-Macmillan), pp228-242.

Kendall, J and Fraisse, L (2009) 'The European Statute of Association: Why Still an Obscure but Contested Symbol in a Sea of Indifference and Scepticism?' in J Kendall (ed.) Handbook on Third Sector Policy in Europe (Cheltenham: Edward Elgar) pp209-228.

Kingdon, J (1995) Agendas, Alternatives and Public Policy (New York: Harper Collins).

Leiren. M and Parks, L (2014) 'When Trade Unions succeed. Cases of blocked liberalisation in the Common Market, European Journal of Political Research, 53, 3, 465-479.

Lukes, S (1974) Power: a radical view (Basingstoke and New York: Macmillan).

Marks, G and McAdam, D (1996) 'Social Movement and the Changing Structure of Political Opportunity in the European Union', in G Marks, W Scharpf, P Schmitter and W Streeck (eds.) Governance in the European Union (London: Sage), pp.95-120.

Mason, D (2012) 'Lobbyists will not hijack petition scheme, EU insists', http://www. publicserviceeurope.com/article/1412/lobbyists-will-not-hijackpetition-scheme-eu-insists, accessed on 15.06.2013.

Mc Adam D, McCarthy J and Zald M (eds.) Comparative Research on Social Movements (Cambridge: Cambridge U P).

Pfafferott, C (2013) ECl Day in Brussels: civil society, make it work! http://www.democracy-international.org/eci-day-brussels.html, accessed on 09.02.2014.

Sabatier, P (1988) 'An advocacy coalition framework of policy change and the role of policy-oriented learning therein', Policy Sciences 21: 129-168.

Sabatier, P (1998) 'The Advocacy Coalition Framework: revisions and relevance for Europe', Journal of European Public Policy, 5, 1, 98-130. 
'This is an electronic pre-publication (including pre-proofs) version of an article published in $H$ Johansson and S Kalm (eds.) EU Civil Society: Patterns of Cooperation, Competition and Conflict (Basingstoke: Palgrave Macmillan), and available at https://www.palgrave.com/gb/book/9781137500700

Sabatier, P and Jenkins-Smith, H (1999) 'The Advocacy Coalition Framework: An Assessment', in P Sabatier (ed.) Theories of the Policy Process (Boulder, Westview Press), pp.117-166.

Smith, G. (2009) Democratic Innovations (New York: Cambridge University Press).

Social Platform (2000) 'Response of the Platform of European Social NGOs; The Commission and Non-Governmental Organisations: Building a Stronger Partnership', Brussels, 27 April 2000, http://ec.europa.eu/civil_society/ngo/commun/contributions.htm accessed on 23.11.2012.

Social Platform (2002) 'Submission to consultation document 'Towards a Reinforced Culture of Consultation and Dialogue)' Brussels, $30 \mathrm{~J}$ uly 2002, http://www. europa.eu.int/comm/secretariat_general/sgc/consultation/docs/cont socplat.pdf accessed on 3.7.2005.

Social Platform (2010a) 'How to establish an effective dialogue between the EU and civil society organisations', http://ec.europa.eu/dgs/secretariat_general/citizens_initiative/docs/social_platfo rm en.pdf accessed on 25.11.2014.

Social Platform (2010b) Green Paper on citizens' initiative - complement it with a consultation on how to organise the dialogue with civil society organisations, as provided by article 11 of the Lisbon Treaty, http://ec.europa.eu/dgs/secretariat general/citizens initiative/contrib orga en. htm accessed on 25.11.2014.

Social Platform (2014a) 'What we do', http://www. socialplatform.org/what-wedo/civil-dialogue/ accessed on 10.02.2014.

Social Platform (2014b) http://www.socialplatform.org/what-we-do/civildialogue/partnerships/ accessed on 25.11.2014.

Sudbery, I. (2003) 'Bridging the Legitimacy Gap in the EU: Can Civil Society Help to Bring the Union Closer to Its Citizens', Collegium: 26, spring, pp75-95.

Warleigh, A. (2001) 'Europeanizing Civil Society: NGOs as Agents of Political Socialization', J ournal of Common Market Studies, November, 39 (4): 619-639. 
'This is an electronic pre-publication (including pre-proofs) version of an article published in

$H$ Johansson and S Kalm (eds.) EU Civil Society: Patterns of Cooperation, Competition and Conflict (Basingstoke: Palgrave Macmillan), and available at https://www.palgrave.com/gb/book/9781137500700

20

'European Commission or European Economic and Social Committee jointly hosted events with the European Citizen Action Service held in Vienna in October 2012, and in Brussels in November 2012 and April 2014.

ii With weighted minimum quotas specified for each member state.

iii 1,364,984; European Disability Forum (undated).

iv Examples include the ECls calling for a 'High Quality European Education for All', Fratenité 2020, and 'Suspension of the EU Climate and Energy Package'. Some of these campaign websites have been relinquished following the end of the campaign.

$\checkmark$ 'One million signatures for a Europe of solidarity' Case T-450/12, Anagnostakis v Commission; 'Right to Lifelong Care: Leading a life of dignity and independence is a fundamental right!' Case T44/14, Costantini and Others v Commission; 'Minority Safe Pack - one million signatures for diversity in Europe' Case T 529/13 Izsak \& Dabis v Commission; Stop TTIP, Case 754/14 Efler \& Others - v - Commission. 